\title{
Van hard werken is nog nooit iemand doodgegaan
}

\author{
Citation for published version (APA):
}

Kant, IJ. (2010). Van hard werken is nog nooit iemand doodgegaan. Maastricht University. https://doi.org/10.26481/spe.20100701ijk

Document status and date:

Published: 01/07/2010

DOI:

10.26481/spe.20100701ijk

Document Version:

Publisher's PDF, also known as Version of record

\section{Please check the document version of this publication:}

- A submitted manuscript is the version of the article upon submission and before peer-review. There can be important differences between the submitted version and the official published version of record.

People interested in the research are advised to contact the author for the final version of the publication, or visit the DOI to the publisher's website.

- The final author version and the galley proof are versions of the publication after peer review.

- The final published version features the final layout of the paper including the volume, issue and page numbers.

Link to publication

\footnotetext{
General rights rights.

- You may freely distribute the URL identifying the publication in the public portal. please follow below link for the End User Agreement:

www.umlib.nl/taverne-license

Take down policy

If you believe that this document breaches copyright please contact us at:

repository@maastrichtuniversity.nl

providing details and we will investigate your claim.
}

Copyright and moral rights for the publications made accessible in the public portal are retained by the authors and/or other copyright owners and it is a condition of accessing publications that users recognise and abide by the legal requirements associated with these

- Users may download and print one copy of any publication from the public portal for the purpose of private study or research.

- You may not further distribute the material or use it for any profit-making activity or commercial gain

If the publication is distributed under the terms of Article $25 \mathrm{fa}$ of the Dutch Copyright Act, indicated by the "Taverne" license above, 


\section{Van hard werken is nog nooit iemand doodgegaan}

Oratie

Uitgesproken bij de aanvaarding van het ambt van bijzonder

hoogleraar epidemiologie i.h.b. arbeidsepidemiologie aan Maastricht University, Faculty of Health, Medicine and Life Sciences.

Maastricht, 1 juli 2010

Door Prof. Dr. IJ . Kant 
Mijnheer de Pro-Rector,

Waarde Collega's, lieve familieleden en vrienden,

Zeer gewaardeerde toehoorders,

\section{Inleiding}

Daags na het versturen van de uitnodigingen voor deze oratie mocht ik reeds de eerste van vele reacties op de titel van mijn oratie ontvangen. Van collega wetenschappers, als van arbo-artsen uit het veld ontving ik zowel ontkenningen als bevestigingen van de hier getoonde stelling. Sommigen stuurden zelfs ter onderbouwing wetenschappelijke literatuur mee.

Anderen vroegen zich af of deze titel te maken had met mijn nieuwe manier van leidinggeven of dit was voortgekomen uit mijn opvoeding. Weer anderen hebben deze spreuk op het stuur van de auto geplakt ter aanmoediging van iedere nieuwe werkdag.

Het onderstreept in ieder geval dat werk voor velen een belangrijk element in het bestaan is. Het verzekert ons niet alleen van een inkomen maar biedt tevens de mogelijkheden tot ontplooiing, geeft structuur aan ons leven en zorgt sociale kontakten. Als zodanig heeft werk veel positieve kanten.

In mijn oratie wil ik echter vooral stilstaan bij de mogelijk negatieve gezondheidsaspecten van werk en hoe de arbeidsepidemiologie als wetenschap een positieve bijdrage kan leveren aan het verminderen van gezondheidsschade.

De gezondheid van werknemers kan op vele manieren bedreigd worden,

Tijdens het werk kunt $u$ worden blootgesteld aan chemische stoffen, biologische agentia, ergonomische factoren zoals een verkeerde werkhouding, tillen maar ook aan fysische factoren zoals lawaai en straling. Bij veelvuldige blootstelling hieraan kunnen allerlei gezondheidsklachten en ziekten ontstaan.

Om gezondheidschade door werk te voorkomen zijn drie zaken onontbeerlijk:

- Wetenschappelijke kennis van de oorzakelijke relatie tussen blootstelling en gezondheid.

- De financiële organisatorische en technische mogelijkheden om deze kennis te vertalen naar een gezonde werkplek.

- De politieke en maatschappelijke wil om door middel van wetgeving en handhaving een gezonde werkplek te waarborgen. 
Wanneer aan deze voorwaarden niet wordt voldaan leidt dit bijna altijd tot gezondheidsschade van werknemers. I k wil dit toelichten aan de hand van de ontdekking en toepassing van de chemische stof: koolstof di-sulfide [1].

Koolstof disulfide $\left(\mathrm{CS}_{2}\right)$ wordt in 1796 ontdekt. Aanvankelijk wordt het gebruikt als medicijn gebruikt. Vanwege de bedwelmende eigenschappen wordt het ook als anesteticum gebruikt. Het oplosmiddel blijkt heel toepasbaar bij het verstevigen van rubber en vanaf 1850 wordt het op industriële schaal toegepast. Vrijwel gelijkertijd met de industriële toepassing worden de eerste gezondheidsklachten en symptomen van $\mathrm{CS}_{2}$ vergiftigingen in Frankrijk beschreven o.a door Louis Depeche. Lange tijd worden de symptomen van vergiftigingen genegeerd en toegeschreven aan de werknemer zelf. Zo noemt de Franse arts Charcot in 1889 de symptomen 'carbon disulfide neurose'. Hij wilde hiermee aangeven dat maar een klein deel van de symptomen van de stof carbon-disulfide kwamen maar het merendeel toe te schrijven was aan hysterie van de werknemer.

In 1902 worden ernstige gevolgen van $\mathrm{CS}_{2}$ vergiftigingen in de Franse en Engelse rubberindustrie beschreven door Olliver in zijn boek 'dangerous trades'.

- Lage dosis: vermoeidheid, duizeligheid, overgeven

- Hoge dosis: Acute krankzinnigheid en uit het raam springen. Ondanks deze dodelijke ongevallen wordt er niets gedaan aan de arbeidsomstandigheden of het verbeteren van ventilatie, maar worden tralies voor de ramen geplaatst! Het duurt nog tot 1938 voordat er serieuze onderzoeken naar de gevolgen van $\mathrm{CS}_{2}$ worden uitgevoerd.

Onder invloed van de sociale hervormingen word de eerste wetgeving op het gebied van arbeid ingesteld en worden de ergste uitwassen uitgebannen.

Pas na de tweede wereldoorlog wordt er veel wetenschappelijk onderzoek gedaan naar de relatie tussen werk en gezondheid. Zo worden op basis van toxicologisch en epidemiologisch onderzoek grenswaarden opgesteld waarbinnen nog veilig gewerkt kan worden met chemicaliën. Als gevolg hiervan treden er in de westerse wereld aanzienlijke reductie op van veel beroepsmatige blootstellingen. Als gevolg hiervan zijn dan ook veel beroepsziekten, zoals silicose, beroepsastma en lawaaidoofheid, teruggedrongen.

Dat kennis en inzicht in de risico's van het werk en goede handhaving van regels tot een gezonde werkplek kunnen leiden tonen een aantal 
studies aan, die binnen het programma van epidemiologie van arbeid en gezondheid werden uitgevoerd.

Het betreft drie groepen werknemers waarvan u gevoelsmatig inschat dat dit geen gezonde beroepen kunnen zijn.

De eerste groep betreft werknemers in de Belgische kerncentrales in o. a Tihange en Doel. Het mogelijke risico voor deze werknemers bestaat uit nucleaire straling. Deze werknemers werden in de periode 1969 tot 1994 opgevolgd wat betreft sterfte [2]. Uit dit onderzoek bleek dat het risico om te overlijden in deze periode 0,63 was ten opzichte van de algehele bevolking in deze periode (SMR). Dit betekent dat de sterfte $37 \%$ lager is dan voor de algemene bevolking. Ook de sterfte ten gevolge van kanker was veel lager dan in de algemene bevolking. Ook studies in de chemische industrie, naar werknemers blootgesteld aan acrylamide en de bestrijdingsmiddelen Dieldrin en Aldrin, tonen aan dat mits aan de normen wordt voldaan, de sterfte lager is dan in de algemene bevolking [3].

\section{Arbeidsepidemiologie}

De studies zoals boven beschreven zijn voorbeelden van arbeidsepidemiologische studies. Epidemiologie is de wetenschap gericht op de bestudering van ziektepatronen in de populatie en de factoren die daarop van invloed zijn. Epidemiologen onderzoeken dus waarom sommige mensen wel ziek worden en anderen niet en waarom sommige patiënten beter worden en anderen niet.

Als zodanig kan de Epidemiologie een bijdrage leveren aan de onderbouwing van het medisch handelen en aan de onderbouwing van interventies in de publieke gezondheidszorg.

In de Epidemiologie staan de volgende 6 vragen centraal:

- Welke ziekte of aandoening betreft het? (diagnose)

- Hoe vaak komt de ziekte in de populatie voor? (prevalentie)

- Hoe veel nieuwe ziektegevallen ontstaan per jaar in deze populatie? (incidentie)

- Welke factoren dragen bij aan het ontstaan van de ziekte? (etiologie)

- Wat is het beloop van de ziekte en welke factoren bepalen dit verloop? (prognostiek)

- Welke interventie / behandeling kan herstel bevorderen? (therapie)

Arbeidsepidemiologie is een sub discipline van de epidemiologie en richt zich op de werkende bevolking. Het doel van het arbeidsepidemiologisch onderzoek is een bijdrage te leveren aan 
gezondheid en welzijn van werknemers en arbeidsongeschiktheid te reduceren.

Dit wordt verwezenlijkt door het:

- Bestuderen van het ontstaan, beloop en behandeling van verschillende gezondheidsklachten en ziektes binnen de werkende populatie.

- Ontwikkelen en evalueren van:

o instrumenten en strategieën voor preventie

o behandeling van aandoeningen

Het huidig arbeidsepidemiologische onderzoek binnen de faculteit of Health, Medicine and Life Sciences, is gepositioneerd binnen het aandachtsgebied Epidemiologie van Arbeid en Gezondheid van de capgroep Epidemiologie.

De onderzoeksactiviteiten vinden plaats binnen het cluster Public Health van de onderzoeksschool Public Health and Primary Care.

De instelling van de bijzondere leerstoel epidemiologie i.h.b van arbeid binnen de FHML betekent een versterking van het dit type onderzoek. In het tweede deel van mijn oratie zal ik nader ingaan op de ontwikkelingen in de arbeidsepidemiologie en mijn visie op de wetenschappelijke uitdagingen waarvoor we staan.

\section{Maatschappelijke ontwikkelingen en gevolgen voor Arbeid en Gezondheid}

Terwijl de chemische en fysische risico's de afgelopen decennia sterk zijn afgenomen, is door maatschappelijke en economische ontwikkelingen het werk sterk veranderd en zijn nieuwe gezondheidsrisico's in het werk opgekomen.

Een belangrijke ontwikkeling is dat de welvaart sinds de tweede wereldoorlog enorm is gestegen, zoals te zien in onderstaande figuur [4]. Deze figuur toont de welvaartsstijging over de periode 1948 tot 2008, dit is de rode lijn. In deze periode is de welvaart meer dan verviervoudigd. Gelijkertijd is de totale arbeidsduur per inwoner in Nederland nauwelijks gestegen. De figuur laat tevens zien dat de welvaartstijging vrijwel geheel betaald is uit de verhoging van de arbeidsproductiviteit, dit is de blauwe lijn. 
1. Bbp per inwoner, arbeidsproductiviteit en arbeidsduu $\mathrm{r}^{\mathbf{2}}$

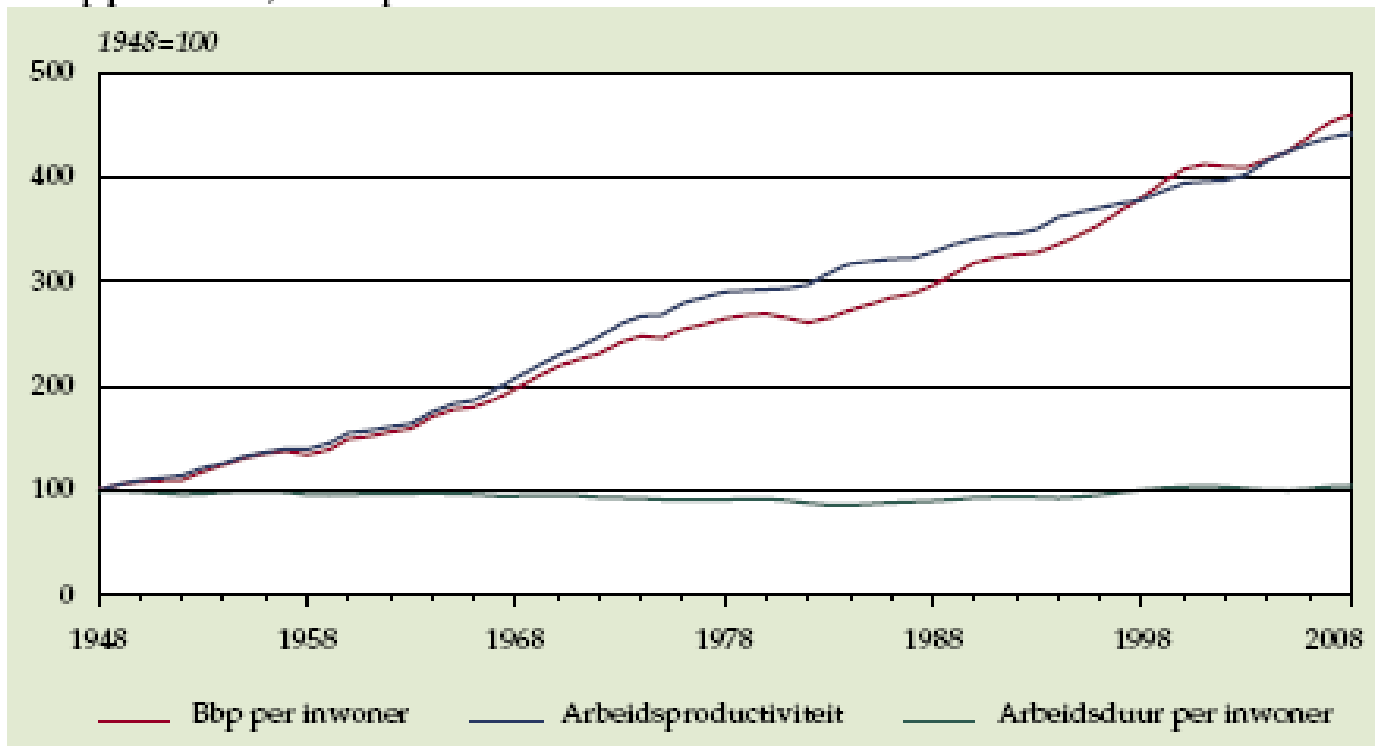

Bron: CBS, Nationale rekeningen 2008.

1) De arbeidsdutur is uitgedrukt in arbeidsjaren; hiervan is cok gebruik gemaakt bij de bepaling van de arbeidsproductiviteit.

In de zelfde periode is ook de deelname van vrouwen aan het arbeidsproces sterk toegenomen en is er tegelijkertijd een andere verdeling van werk en zorg taken ontstaan. Daarnaast heeft de globalisering van de economie geleid tot het ontstaan van een 24 uurs economie. Al deze ontwikkelingen hebben grote gevolgen voor de aard en inhoud van het werk.

Ten behoeve van de productiviteitsverhoging is veel werk geautomatiseerd en is er een verschuiving opgetreden van fysieke naar mentale arbeid.

Ook is het werk intensiever geworden wat weerspiegeld wordt in een grotere werkdruk. De resultaten van de Fourth European Working Conditions Survey laten zien dat in de periode 1991-2005 de intensiteit, in termen van deadlines en hoog tempo van het werk, in geheel Europa zijn toegenomen [5]. Daarbij zijn er wel grote verschillen tussen Europese landen onderling. Nederland neemt hierbij een middenpositie in.

De 24 uur economie geleid tot flexibilisering van de arbeid en daarmee geleid tot een grote verscheidenheid aan verschillende werktijdregelingen. Van alle werknemers in Nederland werkt $14 \%$ in een of andere vorm van ploegendienst. Door de flexibilisering zijn ook de grenzen tussen werk en privé in termen van plaats en tijd deels verdwenen. 


\section{Belang van een goede psychosociale werkomgeving neemt toe}

Door al deze verschuivingen wordt naast een gezonde fysieke werkomgeving ook een goede psychosociale werkomgeving steeds belangrijker. Wat verstaan we eigenlijk onder deze psychosociale werkomgeving?

Zoals de naam al doet vermoeden heeft de psychosociale werkomgeving te maken met enerzijds de psychologische belasting in het werk en anderzijds de sociale aspecten waaronder het werk dient te worden uitgevoerd.

De psychosociale werkomgeving kent drie domeinen. De eerste wordt gevormd door de taakeisen die het werk stelt, zoals het tempo en de tijd waarin het werk gedaan moet worden, maar ook of de taakeisen bijvoorbeeld psychologisch, emotioneel of cognitief van aard zijn. Het tweede domein betreft de inhoud en zingeving van het werk en de mogelijkheid om zelf het werk in te delen.

Het derde domein betreft inter-persoonlijke relaties en leiderschap. Hierbij valt te denken aan steun van leidinggevenden en directe collega's, maar ook aan taakonduidelijkheid of conflicten.

Bij alle drie de domeinen geldt dat ze positieve en negatieve kanten kunnen hebben. Bovendien kunnen deze domeinen elkaar wederzijds beïnvloeden. Daarmee onderscheidt de psychosociale werkomgeving zich van de fysieke werkomgeving in die zin dat we bij de psychosociale werkomgeving elkaars werkomgeving vormen en waar je dus of je wilt of niet onderdeel van uit maakt.

Een andere essentie van dit overzicht is dat naarmate de taakeisen zwaarder worden, het belang van goede werkafspraken, zingeving, maar ook sociale steun aan belang toenemen. Aan de hand van het volgende voorbeeld wil ik dit illustreren.

Stel, u gaat voor uw ontspanning op zondagmiddag een fietstochtje op de Veluwe maken. Een dergelijke activiteit vraagt nauwelijks voorbereiding of afstemming. $U$ gaat op reis en neemt mee: wellicht een fietskaart van de Veluwe, een regenjas, een flesje water en misschien een lunchpakketje. En over de route wordt $u$ het tijdens de tocht wel eens. Vergelijkt u dit eens met een profwielerwedstrijd, waaraan aan de individuele wielrenners extreem hoge taakeisen worden gesteld. Dit vraagt een goede afstemming over de route, wie valt waar aan, en wie ondersteunt wie tijdens de koers. Wil de wedstrijd enigszins kans van slagen hebben, dan worden ook hoge eisen gesteld aan het materieel, conditie, en is de support van de mental coach, conditietrainer en fysiotherapeut onontbeerlijk. Met de toegenomen werkdruk lijkt werk hedentendage meer op profwielrennen en werk kan daarmee gezien worden als topsport! 


\section{Toename psychische klachten}

Alle geschetste veranderingen in de arbeid hebben ertoe geleid dat er onder werknemers andere klachten zijn ontstaan. Zo werd er sinds de jaren tachtig van de vorige eeuw een toename van vooral mentale gezondheidsklachten waargenomen onder werknemers. Ook in de statistieken van arbeidsongeschiktheid en ziekteverzuim dook steeds vaker de diagnose psychische klachten op.

Uit schattingen van de overheid werd geraamd dat circa een derde van de klachten en samenhangend verzuim te maken zouden hebben met de psychosociale werkomgeving. Echter, betrouwbare gegevens hieromtrent ontbraken echter veelal. Om deze redenen werd in 1996 door de Nederlandse Organisatie voor Wetenschappelijk Onderzoek een grootschalig landelijk onderzoek naar psychische vermoeidheid in de arbeidssituatie uitgezet.

De Maastrichtse onderzoeksgroep had daarbij de overtuiging dat voor de beantwoording van dit vraagstuk een epidemiologische benadering onontbeerlijk is. Daarom werd vanuit de Universiteit Maastricht aan dit landelijke programma invulling gegeven middels een grootschalige Cohort Studie.

\section{De Maastrichtse Cohort Studie}

De studie werd de Maastrichtse Cohort Studie genoemd [6]. Het doel was inzicht te verkrijgen in de omvang, oorzaken, gevolgen en behandeling van werknemers met vermoeidheidsklachten. Het uiteindelijke doel van deze studie was om te komen tot wetenschappelijk gefundeerde maatregelen om vermoeidheid en de gevolgen daarvan te voorkomen dan wel te reduceren. Dit om te voorkomen dat maatregelen in het werk slechts symptoombestrijding zouden zijn, gelijk het voorbeeld van de tralies bij koolstof di-sulfide.

De Maastrichtse Cohort Studie betreft een grootschalig onderzoek waarin een groot aantal medewerkers uit 45 verschillende bedrijven en instellingen in de tijd werden opgevolgd. In de periode van 1998 tot 2002 ontvingen de deelnemers regelmatig vragenlijsten. Een maal per jaar betrof dit een uitgebreide vragenlijst en twee maal per jaar een relatief korte vragenlijst.

In de vragenlijsten werden vragen gesteld met betrekking tot werkinhoud, privésituatie, en individuele kenmerken. In dezelfde vragenlijsten werden ook verschillende vermoeidheidsuitkomsten en de gevolgen van vermoeidheid nagevraagd. In dezelfde periode 
werden via bedrijfsregistraties de verzuim- en arbeidsongeschiktheidsgegevens van de deelnemers verzameld.

Uit de Maastrichtse Cohort Studie komt naar voren dat iedereen in mindere of meerdere mate vermoeidheid ervaart. De vraag is dan ook wanneer deze vermoeidheid ontoelaatbaar is en het functioneren gaat beïnvloeden. In een aparte studie werd vastgesteld dat deze grens lag bij een score van 76 punten of hoger [7]. Als we dit punt loslaten op deze populatie, dan betekent dit dat bijna $22 \%$ van de werknemers langdurig vermoeid is.

Ontstaan van vermoeidheid Vervolgens werd bekeken hoeveel niet vermoeide werknemers over een bepaalde tijdsperiode toch langdurige vermoeidheid ontwikkelden. Het aantal nieuwe gevallen van vermoeidheid (incidentie) over een jaar bedroeg $11 \%$. Vervolgens werd nagegaan wat nu de reden was voor het ontstaan van deze vermoeidheid bij deze werknemers. Lagen de oorzaken bijvoorbeeld in de psychosociale werkomgeving, de gezondheid of leefstijl, of in de privésituatie?

Verschillende aspecten van de psychosociale werkomgeving verhogen het risico om langdurig vermoeid te raken [8]. Zo gaat het hebben van weinig regelmogelijkheden in het werk bij mannen gepaard met 59\% meer kans op het ontwikkelen van langdurige vermoeidheid vergeleken met mannen die veel regelmogelijkheden in het werk rapporteren. Opvallend is dat conflicten met collega's bij vrouwen tot een ruim twee maal zo hoge kans op vermoeidheid leiden. Over het algemeen gaan hoge psychologische taakeisen, lage regelmogelijkheden en weinig sociale steun van collega's gepaard met een verhoogd risico op langdurige vermoeidheid bij zowel mannen als vrouwen.

Naast de psychosociale werkomgeving werd verder gezondheid, leefstijl en de rol van de privésituatie op het ontstaan van vermoeidheid bestudeerd. Het blijkt dat gezondheid en leefstijlfactoren een zeer grote invloed op het ontstaan van vermoeidheid hebben. Zo is er een duidelijke relatie tussen overgewicht en vermoeidheid en komt langdurige vermoeidheid twee tot drie maal zo vaak voor bij chronisch zieke werknemers.

Ook kenmerken van de privésituatie, zoals het niet goed kunnen combineren van werk en zorgtaken, dragen aanzienlijk bij aan het ontstaan van langdurige vermoeidheid. Werknemers die werk en 
zorgtaken niet goed kunnen combineren hebben een 2.5 maal zo grote kans op het ontwikkelen van langdurige vermoeidheid in de tijd.

Beloop en gevolgen van vermoeidheid

Bij de werknemers die langdurige vermoeidheid ontwikkeld hadden, werd vervolgens het beloop van deze vermoeidheid in de tijd bestudeerd.

De prognose van langdurige vermoeidheid onder werknemers is ronduit slecht te noemen. Van de deelnemers die aan de start van de studie vermoeid waren, bleek na vier jaar nog $40 \%$ nog ernstig vermoeid te zijn. Bij $8 \%$ van de werknemers verslechterde zelfs de vermoeidheid. Na vier jaar hadden deze werknemers alle vermoeidheidskenmerken van het chronisch vermoeidheidssyndroom [9].

In een aparte studie werd nagegaan of behandeling van vermoeide werknemers door de huisarts, middels een cognitieve gedragstherapie, effectief was in het verminderen van vermoeidheid. Dit bleek helaas niet het geval.

Opvallend bij het beloop van vermoeidheid is de overeenkomst met burnout. Hoewel vermoeidheid en burnout een aantal gemeenschappelijke kenmerken hebben, bleek de prognose echter nogal te verschillen. Werknemers met burnout herstelden sneller dan langdurig vermoeide werknemers [10].

Langdurige vermoeidheid an sich blijkt behoorlijke consequenties te hebben, ondermeer op het ontwikkelen van veelvoorkomende infecties, maar heeft ook grote gevolgen voor de loopbaan, ziekteverzuim en arbeidsongeschiktheid.

Zo is de kans op buikgriep bij vermoeide werknemers 33\% hoger dan bij niet-vermoeide werknemers [11]. Opvallend zijn de grote gevolgen van vermoeidheid op de interne en externe mobiliteit [12]. Zo gaat vermoeidheid gepaard met een ruim twee maal zo hoge kans om de arbeidsduur te verminderen. Vermoeidheid geeft zelfs een ruim vier maal zo hoge kans om de ploegendienst te verlaten en in dagdienst te gaan werken. Ook is vermoeidheid voor veel werknemers een aanleiding om intern dan wel extern een andere baan te zoeken. Vermoeidheid heeft verder een grote invloed op ziekteverzuim en arbeidsongeschiktheid. Het risico om arbeidsongeschikt te worden neemt sterk toe bij toenemende vermoeidheid over 32 maanden follow-up [13]. Daarbij heeft de groep werknemers met een vermoeidheidsscore hoger dan 75 een ruim 12 maal zo hoog risico om arbeidsongeschikt te geraken in vergelijking met de groep werknemers die nauwelijks vermoeidheid rapporteren. 
Uit de tot nu toe uitgevoerde studies binnen de Maastrichtse Cohort studie kunnen we concluderen dat:

- Vermoeidheid een veel voorkomende klacht onder werknemers is

- In het ontstaan en beloop van vermoeidheid de psychosociale werkomgeving een grote rol speelt.

- Mogelijkheden voor behandeling beperkt zijn

- Gevolgen vermoeidheid ernstig zijn

Deze bevindingen vormen de basis voor nieuwe onderzoeksterreinen die binnen het programma epidemiologie van arbeid en gezondheid worden uitgevoerd.

\section{Nieuwe onderzoeksterreinen}

Deze nieuwe onderzoeksterreinen richten zich op de volgende vragen

- Hoe kunnen negatieve gevolgen van de psychosociale werkomgeving voorkomen worden?

- Kan een slechte psychosociale werkomgeving bijdragen aan concrete ziektes en een verhoogde sterfte?

- Wat zijn de gevolgen van de psychosociale werkomgeving voor arbeidsparticipatie?

Ik wil deze nieuwe onderzoeksterreinen ieder kort toelichten.

Preventie ziekteverzuim en arbeidsongeschiktheid

Zoals ik heb laten zien draagt een slechte psychosociale werkomgeving

bij tot arbeidsverzuim en arbeidsongeschiktheid. Dit verzuim is vaak langdurig en de re-integratie van deze werknemers is vaak niet succesvol.

Dit heeft geleid tot een verschuiving van de focus van ziekteverzuim begeleiding naar een meer preventieve strategie. Deze preventieve strategie werd in nauwe samenwerking met Arbodienst Beter ontwikkeld. Kenmerken van deze preventieve aanpak zijn dat begeleiding en behandeling plaatsvinden voordat ziekteverzuim is opgetreden. We richten ons hierbij nadrukkelijk op die werknemers die een verhoogd verzuim risico hebben. Een eerste voorwaarde is dan dat je deze werknemers moet kunnen opsporen middels screening.

Op basis van de Maastrichtse Cohort Studie werd daarom een screeningsinstrument ontwikkeld en uitgetest bij een groot aantal medewerkers van ABN AMRO. Het resultaat is de Balansmeter, een vragenlijst waarmee het risico op toekomstig verzuim voorspeld kan worden [14]. De vragenlijst bevat 34 vragen over werk gezondheid en privésituatie. De vragen zijn deels verschillend voor mannen en vrouwen. De voorspellende waarde van de Balansmeter is zondermeer 
goed. Mannen die hoog scoren op de balansmeter hebben een meer dan 13 keer hogere kans op toekomstig verzuim in vergelijking met laagscoorders op de Balansmeter. Voor vrouwen is deze kans bijna zes keer hoger.

Vervolgens is nagegaan of vroegtijdige interventie bij werknemers met een verhoogd verzuimrisico volgens de Balansmeter effectief is in het reduceren van toekomstig verzuim. Dit is uitvoerig nagegaan in een uitgebreide interventiestudie onder werknemers van ABN AMRO [15]. Hoogscoorders op de Balansmeter werden verdeeld over een experimentele en controlegroep. De experimentele groep ontving vroegtijdige begeleiding door de bedrijfsarts. De controlegroep ontving geen behandeling.

Deelnemers in de interventiegroep hadden een significant lagere verzuimduur over 12 maanden follow-up dan de controle groep. Dit verschil is ruim $35 \%$.

Ook de verzuimfrequentie en het percentage langdurig ziekteverzuim was in de interventie groep beduidend lager. Hoewel deze laatste verschillen relevant zijn waren deze niet significant.

Uit deze RCT is bewezen dat screening met de Balansmeter gevolgd door vroegtijdige begeleiding effectief is in het voorkomen van toekomstig langdurig verzuim. Voor deze preventieve aanpak is inmiddels veel belangstelling.

Dit heeft geleid tot de oprichting van de Balansmeter BV, waarin naast de Universiteit Maastricht, ook de Arbodiensten Beter en Achmea Vitale participeren. Het doel van de Balansmeter BV is het gezamenlijk doorontwikkelen en gezamenlijk exploiteren van de Balansmeter. De revenuen hiervan voor de Universiteit Maastricht worden door de Universiteit weer teruggeleid naar mijn onderzoeksprogramma en als zodanig is dit een heel mooie vorm van kennisvalorisatie.

Hoewel we al veel resultaten geboekt met deze preventieve strategie, is er ook nog heel veel te onderzoeken. De oorspronkelijke Balansmeter is ontwikkeld voor mensen werkzaam in een kantooromgeving en is niet bruikbaar in andere settings. Daarom wordt nu gewerkt aan aanvullende Balansmetermodules om de preventieve strategie ook in andere sectoren mogelijk te kunnen maken. Zo werd recent een module voor werknemers in de industrie ontwikkeld en deze module zal binnenkort in de praktijk worden uitgetest.

Verder wordt thans onderzocht of gerichtere interventies voor specifiekere doelgroepen de effectiviteit van de preventieve strategie verder verhogen. Hierbij richten we ons op werknemers met een verhoogd verzuimrisico én depressieve klachten, waarbij vroegtijdige interventie bestaat uit een aangepaste cognitieve gedragstherapie. 
In de bedrijfsgezondheidszorg is geen traditie in screening. Daarom is er dringend behoefte aan een normatief raamwerk voor screening om een grootschalige implementatie in de bedrijfsgezondheidszorg mogelijk te maken. Op dit moment loopt er een project om tot een dergelijk normatief raamwerk te komen.

\section{Lange termijn gevolgen van de psychosociale werkomgeving in termen van ziekte en sterfte}

Een tweede nieuw onderzoeksterrein betreft de lange termijn effecten van de psychosociale werkomgeving op ziekte en sterfte.

De Maastrichtse Cohort Studie heeft aangetoond dat de psychosociale werkomgeving tot klachten kan leiden. Maar het is heel goed denkbaar dat deze invloed veel verder reikt dan de korte termijn en zelfs tot concrete ziektes en sterfte kan leiden.

In ons programma richten we ons vooralsnog op hart- en vaatziekten en depressie. Al geruime tijd is bekend dat werkstress tot hart en vaatziekten kan leiden. In ons onderzoek ligt de nadruk op de methodologie, waarbij geprobeerd wordt om de vele tegenstrijdige resultaten van eerdere studies door anderen, te verklaren.

Het onderzoek naar de relatie tussen de psychosociale werkomgeving en depressie richt zich op drie domeinen. Enerzijds wordt de rol van werk in het ontstaan en beloop van depressieve klachten onder werknemers in kaart gebracht. Werk wordt hierbij niet alleen maar als negatief gezien, maar ook wordt onderzocht of werk als therapeuticum kan dienen. Specifiek wordt gekeken naar de rol van werktijdregelingen en wordt onderzocht hoe depressieve klachten onder bijvoorbeeld ploegendienstmedewerkers uiteindelijk teruggedrongen kunnen worden. Een laatste domein op het gebied van depressie betreft de introductie en evaluatie van een stepped care in de bedrijfsgezondheidszorg teneinde de behandeling van depressie in de bedrijfsgezondheidszorg te optimaliseren.

Bovendien willen we onderzoeken of de psychosociale werkomgeving ook tot een hogere sterfte leidt

Met andere woorden of bijvoorbeeld werkdruk of conflicten op het werk de kans op overlijden verhogen?

Als dit waar is dan onderstreept dit in extreme mate de grote impact van de psychosociale werkomgeving en de noodzaak om dit te voorkomen. Wellicht dat de eerder genoemde preventieve strategie, bestaande uit screening en vroegtijdige interventie, hierin soelaas kan 
bieden, omdat ik vind dat van hard werken niemand dood zou mogen gaan.

Om deze onderzoeken mogelijk te maken heeft het programma Epidemiologie van Arbeid en Gezondheid een vervolg gegeven aan de Maastrichtse Cohort Studie. Hiertoe werden de oorspronkelijke deelnemers aan het cohort in 2008 opnieuw benaderd. De respondenten hiervan worden opgevolgd tot 2011.

Op twee momenten wordt middels vragenlijsten, naast de werkomgeving, de gezondheid en specifieke ziektes nagevraagd.

Daarnaast wordt ook op dezelfde momenten de vitale status van de deelnemers nagegaan via de Gemeentelijke Basisadministratie. Van de overleden deelnemers wordt middels een koppeling met de gegevens van het Centraal Bureau voor de Statistiek de doodsoorzaak achterhaald.

\section{Psychosociale werkomgeving en arbeidsparticipatie}

Een derde nieuw onderzoeksterrein betreft de effecten van de psychosociale werkomgeving op arbeidsdeelname. Onderzoek naar de invloed van de psychosociale werkomgeving op arbeidsdeelname is onder andere ingegeven door het feit dat de overheid arbeidsdeelname wil verhogen. Bovendien wil dezelfde overheid ook de pensioengerechtigde leeftijd verhogen. In deze onderzoekslijn willen we nagaan in hoeverre gezondheid, arbeid en privésituatie bevorderend of belemmerend kunnen zijn voor arbeidsparticipatie en langer doorwerken. Speciale aandacht gaat daarbij uit naar kwetsbare groepen, zoals oudere werknemers en chronisch zieken.

De eerste resultaten van dit onderzoek laten zien dat bij toenemende leeftijd de behoefte aan herstel na het werk in eerste instantie sterk toeneemt. Tegen de verwachting in is de behoefte aan herstel voor de oudste groep werknemers lager [16]. Een mogelijke verklaring kan zijn dat mensen voor wie de arbeidsbelasting te hoog was, reeds gestopt zijn met werken en dat de gezondere werknemers in deze categorie zijn overgebleven. Maar een andere verklaring zou kunnen zijn dat dit te maken heeft met ervaring of copingstrategieën. Dit laatste wordt verder onderzocht om hier voor preventie lering uit te trekken. 


\section{Public health}

In de eerste drie nieuwe onderzoeksterreinen wordt uitsluitend de werkende bevolking bestudeerd. Voor sommige situaties is spiegeling aan een niet-werkende populatie wenselijk.

Op dit terrein is een samenwerking met de GGD Limburg. Recentelijk heeft GGD het initiatief genomen voor een data en kennisnetwerk publieke gezondheid in Limburg. Het programma Epidemiologie van arbeid en gezondheid draagt aan dit initiatief bij middels onze kennis over prospectief cohort onderzoek.

Het data en kennisnetwerk dient ondermeer als een betere onderbouwing van de regionale volksgezondheid en toekomstverkenning. Anderzijds dient dit kennisnetwerk ook voor wetenschappelijk onderzoek. Vanuit het programma willen we het data- en kennisnetwerk gebruiken om vooral een vergelijk tussen werkenden en niet-werkenden mogelijk te maken.

\section{Leerstoel en onderwijs}

Naast de onderzoekstaak is aan het hoogleraarschap ook een essentiële onderwijstaak verbonden. Deze combinatie is mijns inziens onontbeerlijk voor de kwaliteit van het onderwijs. Ik deel dan ook volledig de visie van het onderwijsinstituut van de faculteit dat het wetenschappelijke onderwijs gebaat is bij een directe input van het wetenschappelijk onderzoek.

Vanuit mijn positie als hoogleraar zal ik op twee fronten bijdragen aan het onderwijs.

De eerste bijdrage betreft het methodologie en epidemiologie onderwijs ten behoeve van de diverse bachelor en master opleidingen binnen de FHML.

Een groot accent ligt hierbij op het methodologie onderwijs in jaar 3 van de opleiding Geneeskunde. Hierbij leren we de studenten om middels de Critical Appraisal of a Topic (CAT) benadering een wetenschappelijk onderbouwd antwoord te geven op een klinische vraag voor een specifieke patiënt.

Aan bod komen ondermeer diagnose, prognose, therapie en follow-up van de patiënt.

Samen met de collega docenten hebben we inmiddels veel ervaring met deze methode opgedaan en is de ervaring gebundeld in deze handleiding.

Op dit moment wordt nagegaan of de CAT methode ook bruikbaar is voor de opleiding van arts assistenten en in het hoger beroepsonderwijs bij paramedische opleidingen. 
Een andere bijdrage betreft een voor mij belangrijk streven om binnen het onderwijscurriculum Geneeskunde meer aandacht te verkrijgen voor de context van de ziekte. Ik vind het van groot belang dat toekomstige artsen onderwezen worden dat veel ziektes hun oorsprong in een specifieke omgeving kunnen hebben, bijvoorbeeld werk, of cultuur. Maar ook dat omgekeerd bij elke ziekte sprake is van beïnvloeding van de omgeving door de ziekte.

De herziening van de bachelor geneeskunde en de grotere aandacht daarbij voor wetenschappelijke vorming moeten mijn inziens met beide handen worden aangegrepen om in het curriculum geneeskunde de context van ziekte weer meer aandacht te geven.

\section{Dankwoord}

Dames en heren, Onderzoekers en docenten Epidemiologie van arbeid en gezondheid zijn ook zelf werknemers en hebben zelf ook te maken met een toenemende werkdruk, strakke deadlines en het moeten voldoen aan prestatie indicatoren. Als zodanig is ook voor ons een goede psychosociale werkomgeving van belang.

Onderzoek in de epidemiologie is vooral een kwestie van lange adem. Studies vragen een goede data infrastructuur en duren vaak lang. En resultaten openbaren zich vaak aan het eind. Eerder in deze lezing heb ik werken met topsport vergeleken. Als je epidemiologie wilt vergelijken met een sport dan is het met die van een duursport zoals de 'Tour de France'. Dit vraagt een visie en een langlopend commitment van de organisatie.

I $\mathrm{k}$ ben dan ook het college van bestuur dankbaar voor het in mij gestelde vertrouwen. De instelling van de bijzondere leerstoel epidemiologie i.h.b. van arbeidsepidemiologie binnen de FHML betekent een erkenning en versterking van het arbeidsepidemiologisch onderzoek.

Vanaf deze plaats wil ik ook Guy Widdershoven en Onno van Schayck hartelijk danken voor het in mij gestelde vertrouwen. Jullie hebben als directie van CAPHRI het initiatief genomen voor de instelling van deze leerstoel en mij de ruimte en de mogelijkheden gegeven om het arbeidsepidemiologisch onderzoek tot een apart onderzoeksprogramma binnen CAPHRI te maken en te laten uitgroeten tot wat het nu is.

Voor mijzelf en de onderzoeksgroep is de vakgroep epidemiologie onze thuisbasis. Een heel plezierige thuisbasis want de vakgroep epidemiologie is een goed georganiseerde en stimulerende vakgroep 
waarop je echt op kunt bouwen. Een vakgroep ik graag mijn bijdrage aan wil blijven leveren. Bij deze wil ook de voorzitter van de vakgroep epidemiologie Martin Prins hartelijk danken voor het in mij gestelde vertrouwen. Dank ook aan alle collega's en ex-collega's van de vakgroep epidemiologie voor de plezierige samenwerking. Voor het onderzoek binnen de arbeidsepidemiologie is samenwerking met het Arbo veld onontbeerlijk. Op deze plaats wil ik Ate Berkouwer, Rudy van Leusden en Gladys Tjin a Ton van de Arbo-dienst Beter bedanken voor de plezierige samenwerking. In de bedrijfsgezondheidszorg zijn Arbo-diensten die in wetenschappelijk onderzoek participeren een zeldzaamheid. Jullie vormen daarop een positieve uitzondering. In de afgelopen 10 jaar hebben we nagenoeg onafgebroken in diverse onderzoeksprojecten intensief samengewerkt en zijn we echte research partners geworden. bedankt voor deze plezierige samenwerking waarvan ik hoop dat deze ook in de toekomst zal blijven voortbestaan.

Van meer recentere datum is de intensieve en plezierige samenwerking met Achmea Vitale. Ik wil Wim Overbeeke en Gijsbert van Lomwel van harte danken voor de samenwerking en ik hoop dat we nog vele mooie onderzoeken gaan uitvoeren.

Net als tour de France lijkt epidemiologie een individuele sport met individuele successen maar als je goed kijkt dan zie je dan het beide teamsporten zijn waarbij onderlinge samenwerking hard nodig is om dat succes te behalen. Net als in Tour de France red je het niet alleen maar is de inzet van verschillende talenten zoals sprinters, klimmers, tijdrijders en allrounders onontbeerlijk.

Dit besef, de grote inzet en de goede samenwerking maken mijns inziens het succes van het programma epidemiologie van arbeid en gezondheid. Vanaf deze plek wil ik dan ook de collega's van het programma epidemiologie van arbeid en gezondheid van harte bedanken voor de samenwerking en de loyaliteit.

Met name wil ik Nicole Jansen, Ludovic van Amelsvoort, Danielle Mohren en Nathalie Janssen en J os Slangen bedanken voor de onvoorwaardelijke steun in goede en slechte tijden. Mede door jullie inzet is het programma wat het is nu is. De instelling van de leerstoel zie ik ook als een bekroning van jullie werk. Ik hoop nog lang met jullie te mogen samenwerken.

Ook wil ik de promovendi Monique Lexis, Karolien Driessen, Karolina Szerencsi en Carin de Brouwer bedanken voor de samenwerking. Ik ervaar het als een feest om jullie te mogen begeleiden. Marcus Huibers wil bedanken voor de samenwerking. Marcus, wij kennen elkaar als geen ander. Jouw ideeën inspireren mij en je kritische blik houd mij scherp en dat waardeer ik zeer. 
Mijn hoogleraarschap zou ondenkbaar zijn geweest zonder de aanmoediging en stimulans van velen op cruciale momenten in mijn leven.

Van huis uit is mij het belang van een goede scholing voorgehouden en heb ik, evenals mijn broers en zussen, de gelegenheid en vrijheid gehad om die opleiding te volgen die ik wilde volgen. Mam bedankt daarvoor.

Mijn loopbaan bij de Universiteit Maastricht ben ik begonnen bij de toenmalige vakgroep arbeidsgeneeskunde. Het is mijn leermeester en promotor Pie Henderson geweest die mij op het spoor heeft gezet en heeft aangemoedigd om vanuit een HBO positie te gaan promoveren en mij verder in de wetenschap te bekwamen. Pie bedankt daarvoor. De opheffing van de vakgroep arbeidsgeneeskunde trok een zware wissel op mijn toekomst. Het is Gerard Swaen geweest die mij de mogelijkheid heeft gegeven om mijn loopbaan binnen de universiteit bij arbeidsepidemiologie voort te zetten. Beste Gerard, ik ben je hier nog altijd erkentelijk voor. Bij epidemiologie heb ik altijd de ruimte gekregen om mij verder te ontwikkelen. Ik ben daar Paul Knipschild en Piet van den Brandt zeer erkentelijk voor.

En last but not least wil ik degene die mij het meest na aan het hart zijn: Lilly en Germaine bedanken voor hun liefde, zorg en trouw. Zonder jullie ondersteuning zou ik hier vandaag niet hebben gestaan. Jullie beide humor en relativering zorgen ervoor dat ik niet ontspoor.

Ik heb gezegd. 


\section{Literatuur}

[1] Hunter D. The diseases of occupations. London: Hodder and Stoughton 1978.

[2] Engels H, Swaen GM, Slangen J, van Amelsvoort L, Holmstock L, Van Mieghem $\mathrm{E}$, et al. Radiation exposure and cause specific mortality among nuclear workers in Belgium (1969-1994). Radiation protection dosimetry. 2005; 117(4):373-81.

[3] Marsh GM, Youk AO, Buchanich J M, Kant IJ, Swaen G. Mortality patterns among workers exposed to acrylamide: updated follow up. J Occup Environ Med. 2007; 49(1): 82-95.

[4] Van den Bergen D. Welvaartsgroei en productiviteit. In: De Nederlandse economie 2008. Centraal voor de Statistiek, ed. Voorburg: CBS 2009.

[5] Parent-Thirion A, Macias EF, Hurley J, Vermeylen G. Fourth European Working Conditions Survey. Dublin: European Foundation for the improvement of living and working conditions; 2007.

[6] Kant IJ, Bultmann U, Schroer KA, Beurskens AJ, Van Amelsvoort LG, Swaen GM. An epidemiological approach to study fatigue in the working population: the Maastricht Cohort Study. Occup Environ Med. 2003; 60 Suppl 1:i32-9.

[7] Bultmann U, de Vries M, Beurskens AJ, Bleijenberg G, Vercoulen JH, Kant I. Measurement of prolonged fatigue in the working population: determination of a cutoff point for the checklist individual strength. J Occup Health Psychol. 2000 Oct; 5(4):411-6.

[8] Bultmann U, Kant IJ, Van den Brandt PA, Kasl SV. Psychosocial work characteristics as risk factors for the onset of fatigue and psychological distress: prospective results from the Maastricht Cohort Study. Psychol Med. 2002; 32(2): 333-45.

[9] Huibers MJ, Kant IJ, Knottnerus JA, Bleijenberg G, Swaen GM, KasI SV. Development of the chronic fatigue syndrome in severely fatigued employees: predictors of outcome in the Maastricht cohort study. J Epidemiol Community health. 2004;58(10):877-82.

[10] Leone SS, Huibers MJ , Knottnerus JA, Kant IJ. Similarities, overlap and differences between burnout and prolonged fatigue in the working population. QJ M. 2007;100(10):617-27.

[11] Mohren DC, Swaen GM, Kant IJ, Borm PJ, Galama JM. Associations between infections and fatigue in a Dutch working population: results of the Maastricht Cohort Study on Fatigue at Work. Eur J Epidemiol. 2001; 17(12): 1081-7.

[12] De Raeve L, Kant I, Jansen NW, Vasse RM, van den Brandt PA. Changes in mental health as a predictor of changes in working time arrangements and occupational mobility: results from a prospective cohort study. J Psychosom Res. 2009;66(2):137-45.

[13] van Amelsvoort LG, Kant IJ, Beurskens AJ, Schroer CA, Swaen GM. Fatigue as a predictor of work disability. Occup Environ Med. 2002; 59(10): 712-3. 
[14] Kant IJ, Jansen NW, van Amelsvoort LG, Swaen GM, van Leusden R, Berkouwer A. Screening questionnaire Balansmeter proved successful in predicting future long-term sickness absence in office workers. J Clin Epidemiol. 2009;62(4):408-14 e2.

[15] Kant I, Jansen NW, van Amelsvoort LG, van Leusden R, Berkouwer A. Structured early consultation with the occupational physician reduces sickness absence among office workers at high risk for long-term sickness absence: a randomized controlled trial. J Occup Rehab. 2008; 18(1): 79-86.

[16] Mohren DC, Jansen NW, Kant I. Need for recovery from work in relation to age: a prospective cohort study. Int Arch Occup Environ Health. 2010; 83(5): 553-61. 